\title{
ASSOCIATION FOR ASIAN STUDIES
}

The Association for Asian Studies is a scholarly, nonpolitical, and non-profit professional association open to all persons interested in Asia and the study of Asia. It seeks through publications, meetings and seminars to facilitate contact and exchange of information among scholars and to increase understanding of Asia.

The Association for Asian Studies is the largest society of its kind in the world. It counts among its members scholars, students, business people, diplomats, journalists, and interested laypersons.

Membership forms are available by contacting the AAS Secretariat at:

Association for Asian Studies

1 Lane Hall

University of Michigan

Ann Arbor, MI 48109

\section{AAS ANNUAL MEETING}

The Fortieth ANNUAL MEETING of the

ASSOCIATION FOR ASIAN STUDIES

will be held at the San Fransciso Hilton and Tower,

San Francisco, California

March 25-27, 1988

Expected attendance: 2000 
Modern Asian Studies is concerned with the history, geography, politics, sociology, literature, economics and social anthropology of South Asia, South-East Asia, China and Japan. Contributions should be based on original research or field-work.

All articles (text, notes and references) must be clearly typed in double spacing throughout on one side only of the paper-preferably A4. Two copies should be submitted. Spelling, dates, references and footnote numbers should be checked for accuracy. The use of diacritical marks, italics and capital letters should be kept to a minimum. References repeated in the footnotes should be by author and short title; or the Harvard system of citation may be used.

The title of the article and the author's name and affiliation should be typed on a separate page at the beginning of the article.

Tables should be clearly laid out and numbered consecutively. Vertical lines between columns should be omitted. All figures and totals should be checked for accuracy.

Maps and figures should be clearly legible in every detail. The spelling of place names should be consistent with that used in the text.

Every table, map and figure should have a title and at least one reference in the text to indicate its location.

First proofs only will be sent to the author who will be expected to return them to the Editor within three days. Excessive alterations and additions may be charged to the author.

Each author will receive twenty-five free offprints of his article and a copy of the part of the journal in which it appears.

Submission of an article will be taken to imply that it has not been previously published and that it is not on offer to any other publisher. In the interests of authors, copyright is normally assigned to Cambridge University Press. The editor welcomes expression of all shades of opinion, but responsibility for them rests with their authors. All correspondence should be addressed to Dr Gordon Johnson, Selwyn College, Cambridge $\mathrm{CB}_{3}$ 9DG, England.

(C) Cambridge University Press 1987

\section{Copying}

This journal is registered with the Copyright Clearance Center, 2 I Congress St., Salem, Mass. o 970 . Organizations in the USA who are also registered with CCC may therefore copy material (beyond the limits permitted by sections 107 and 108 of US Copyright law) subject to payment to CCC of the per-copy fee indicated in the code on the first page of the article. This consent does not extend to multiple copying for promotional or commercial purposes.

ISI Tear Service, 350 I Market Street, Philadelphia, Pennsylvania 19104, USA, is authorised to supply single copies of separate articles for private use only.

For all other use, permission should be sought from Cambridge or the American Branch of Cambridge University Press.

Claims for missing issues should be made immediately upon receipt of the subsequent issue. 


\title{
MODERN ASIAN STUDIES
}

\author{
VOLUME 2 I PART 3 JULY I 987
}

ARTICLES

PAGE

Yen Ching-Hwang: Class Structure and Social Mobility in the Chinese Community in Singapore and Malaya I8oo-I9 I I

Stephen P. Blake: The Urban Economy in Premodern Muslim India: Shahjahanabad, I639-1 739

Lakshmi Subramanian: Banias and the British: the Role of Indigenous Credit in the Process of Imperial Expansion in Western India in the Second Half of the Eighteenth Century

Ratnalekha Ray: The Changing Fortunes of the Bengali Gentry under Colonial Rule Pal Chaudhuris of Mahesganj, I 800-I950

I. D. Derbyshire: Economic Change and the Railways in North India, I860-I9 I 4

Omкar Goswami: Multiple Images: Jute Mill Strikes of 1929 and I937 Seen Through Other's Eyes

Colin Simmons: The Great Depression and Indian Industry: Changing Interpretations and Changing Perceptions 